\title{
Radiosensitization of clioquinol and zinc in human cancer cell lines
}

\author{
Shan $\mathrm{Lu}^{1,2,3 \dagger}$, Yuan Ke $\mathrm{K}^{1,2,3 \dagger}$, Chaoyan $\mathrm{Wu}^{4}$, Yahua Zhong ${ }^{2,3}$, Conghua Xie ${ }^{2,3}$, Yunfeng Zhou ${ }^{2,3}$, Fuxiang Zhou ${ }^{2,3^{*}}$ \\ and Haijun $Y u^{2,3^{*}}$ (D)
}

\begin{abstract}
Background: We previously reported that clioquinol acts as a zinc ionophore and inhibits the NF-kB signalling pathway. Other research has demonstrated that zinc deficiency plays a vital role in the occurrence and development of some solid tumours, and intracellular zinc supplementation may reverse this process and enhance the tumour sensitivity to anticancer treatment. Thus, we investigated the radiosensitization effects of clioquinol combined with zinc on HeLa and MCF-7 cells in vitro.
\end{abstract}

Methods: The dose effect of growth inhibition of clioquinol combined with zinc on cell viability was determined by a cell counting kit 8 (CCK-8) assay. The radiosensitization effect of clioquinol combined with zinc and/or MG132 in HeLa and MCF-7 cells was detected by the clonogenic assay. The cell cycle distribution and apoptosis of clioquinol combined with zinc on HeLa cells were analyzed by flow cytometry. A luciferase reporter construct was used to study the effect of clioquinol combined with zinc on NF-kB activity in HeLa cells. DNA double-strand breaks were detected by immunofluorescence. The mRNA and protein levels of ATM were analyzed by quantitative realtime PCR and Western blotting, respectively.

Results: Our research showed that clioquinol combined with zinc markedly increased the radiosensitivity of HeLa and MCF-7 cells in low toxic concentrations and resulted in a post-irradiation decrease in G2 phase arrest and an increase in apoptosis. Clioquinol combined with zinc also inhibited NF-KB activation, decreased ATM expression and increased DNA double-strand breaks (DSBs) induced by ionizing radiation.

Conclusions: These findings indicated that clioquinol combined with zinc enhanced the radiosensitivity of HeLa and MCF-7 cells by the down-regulation of ATM through the NF-KB signalling pathway.

Keywords: Clioquinol, Zinc, Radiosensitization, NF-kB, DNA damage

\section{Background}

Radiation therapy shows a significant clinical benefit in anticancer therapy. However, some solid tumours are resistant to radiation therapy, and the main reason is attributed to the radioresistance of individual cancer cells. Novel radiosensitizing agents can bring substantial benefit, demonstrating high radiosensitive efficiency and low cytotoxicity [1].

Zinc is a crucial trace element playing important roles in diverse physiological processes, such as growth, development, immune functions, and in the intracellular

\footnotetext{
* Correspondence: fuxiang.zhou@whu.edu.cn; doctoryhj@126.com ${ }^{\dagger}$ Equal contributors

${ }^{2}$ Department of Radiation and Medical Oncology, Zhongnan Hospital of Wuhan University, Wuhan, China

Full list of author information is available at the end of the article
}

activity of numerous enzymes and transcription factors [2]. It is also effective in suppressing oxidative stress, clearing free radicals, sustaining genomic stability and decreasing the generation of inflammatory cytokines such as IL-1 $\beta$ and TNF- $\alpha$ [3]. Dysregulation of Zinc is associated with various pathological processes, especially tumour development [4].

Evolving and compelling evidence has shown that zinc is implicated as an important cytotoxic/tumour suppressor agent in several cancers. A recent meta-analysis showed that decreased zinc levels in serum and cancer tissue were found in patients with lung, head and neck, liver, stomach, and prostate cancers [5]. Serum zinc level assessment may improve cancer screening by identifying which patients should be subjected to further testing. 
Such procedures may increase the early detection of cancer. Thus, the zinc status may be a better indicator of the tumour burden and stage of disease than the overall nutritional status. Regulation of the intracellular zinc level will be a novel anticancer therapy. An increasing number of studies has indicated that zinc may be a significant radiosensitizing agent. First, zinc differentially modulates DNA damage in normal and cancer cells. Zinc protects normal cells against DNA damage, an effect that increases in tumour cells $[6,7]$. Second, it has even been proposed that decreased serum zinc levels is a possible biomarker in cancer patients [5].

We have previously demonstrated that clioquinol (5chloro-7-iodo-8-hydroxyquinoline, CQ) acts as a zinc ionophore and generates free zinc in lysosomes, leading to their disruption and apoptotic cell death [8]. Clioquinol (CQ), a derivative of chloroquine, has been used for many years as an inexpensive antifungal and antiparasitic agent and, subsequently, as a potential treatment for Alzheimer's disease. More recently, it has been shown to induce cytotoxic effects in some malignant cells, acting as an ionophore with zinc-binding formation [9]. CQ has shown positive effects in the presence of zinc when combined with chemotherapy. To our knowledge, there are no reports concerning the effect of CQ and zinc on the radiosensitivity of tumour cells. If we can understand how they influence the response to DNA damage induced by ionizing radiation, it may be possible to use them more effectively in the clinical setting. In the present study, we aimed to investigate the radiosensitizing effects of $C Q$ and zinc and their underlying mechanisms in vitro.

\section{Methods}

\section{Reagents}

Analytical grade clioquinol and zinc chloride were purchased from Sigma Chemical Co (Sigma Chemical Co, St. Louis, MO). CQ was dissolved in dimethylsulfoxide (DMSO, Solon, $\mathrm{OH}$ ) to $10 \mathrm{mmol} / \mathrm{L}$ as stock solution (-20 ${ }^{\circ} \mathrm{C}$ storage) and was diluted by MEM to a final concentration. Zinc chloride was dissolved in deionized water to $1 \mathrm{mmol} / \mathrm{L}$ as a stock solution $\left(-20{ }^{\circ} \mathrm{C}\right.$ storage). The proteasome inhibitor MG132 was obtained from EMD Biosciences Inc. (San Diego, CA, USA). Antibodies against ATM, $\gamma$-H2AX, p65 and $\beta$-actin were obtained from Santa Cruz Biotechnology (Santa Cruz, CA, USA). The pNF-kB-Luc reporter construct was from BD Biosciences Clontech (Palo Alto, CA, USA), and the luciferase reporter assay kit was purchased from Promega (Madison, WI, USA).

\section{Cell culture and cell viability assay}

HeLa (catalog number: ATCC ${ }^{\circ} \mathrm{CCL}-2^{\mathrm{Tm}}$ ) and MCF-7 $\left(\right.$ ATCC $^{\bullet} \mathrm{HTB}^{2}-22^{\mathrm{Tw}}$ ) cells were obtained from the American
Type Culture Collection. Cells were cultivated in MEM (minimum essential medium) supplemented with $10 \%(\mathrm{v} / \mathrm{v})$ FCS (foetal calf serum), $100 \mathrm{units} / \mathrm{ml}$ penicillin and $100 \mu \mathrm{g} /$ $\mathrm{ml}$ streptomycin and were routinely grown in a $25-\mathrm{cm}^{2}$ flask under a humid environment at $37{ }^{\circ} \mathrm{C}, 5 \% \mathrm{CO}_{2}$. Cell viability was analyzed using a modified tetrazolium assay and a Cell Counting kit 8 (CCK-8, Beyotime, China) according to the manufacturer's protocol. In brief, HeLa cells were plated in a 96-well tissue culture plate (2000 cells per well) with $100 \mu \mathrm{l}$ of medium, which ensured 40-60\% confluence after $24 \mathrm{~h}$ of growth. The medium was then replaced with $100 \mu \mathrm{l}$ of fresh medium containing CQ and zinc chloride (Sigma Chemical Co: St. Louis, MO) at various concentrations, and the cells were grown for designated periods. To each well, $10 \mu \mathrm{l}$ of the CCK- 8 was added, and cells were incubated at $37{ }^{\circ} \mathrm{C}$ for $2 \mathrm{~h}$ to allow colour development. The plate was read at $450 \mathrm{~nm}$, and the data were expressed as percentages of the values obtained from untreated control cells.

\section{Clonogenic assay}

Cells were seeded into six-well plates at 100-2,000 cells/ well depending on the dose of irradiation. Twenty-four $\mathrm{h}$ after seeding, cells were treated with DMSO, $5 \mu \mathrm{M}$ $\mathrm{CQ}+10 \mu \mathrm{M}$ zinc, $50 \mu \mathrm{M} \mathrm{MG} 132+5 \mu \mathrm{M}$ CQ + $10 \mu \mathrm{M}$ zinc (MG132 for $2 \mathrm{~h}$ prior to $\mathrm{CQ}$ and zinc), and then were exposed to various doses $(0,1,2,4,6,8$ and $10 \mathrm{~Gy})$ of $\gamma$ radiation from linear accelerators (Primus HighEnergy Siemens) at a dose rate of $2 \mathrm{~Gy} / \mathrm{min}$; a $1.5-\mathrm{cm}$ bolus was used as a compensator, and the source skin distance (SSD) was $100 \mathrm{~cm}$. After irradiation, cells were then grown for 10-14 days to allow for colony formation. Following that, cells were fixed and stained using crystal violet. Colonies with 50 or more cells were counted. The sensitizer enhancement ratio (SER) and other radiosensitization parameters were measured using GraphPad Prism 5.0 software according to the multitarget, single-hit model.

\section{Measurement of apoptosis}

Cells were treated with CQ and zinc or DMSO for $4 \mathrm{~h}$ prior to treatment with $6 \mathrm{~Gy}$ of irradiation. Apoptosis was measured using propidium iodide (PI)/Annexin V-FITC double staining following the manufacturer's instructions (BestBio Biotech, Shanghai, China) by method previously reported [10]. Cells were harvested $24 \mathrm{~h}$ after treatment with 6 Gy of irradiation, and the apoptotic fractions were measured using flow cytometry (Beckman, USA). Annexin-V+/PI- indicated early phase of apoptosis, while Annexin-V $+/ \mathrm{PI}+$ indicated late phase. The percentage of both cell types was counted. The data were expressed as the percentage of apoptotic cells per field. 


\section{Cell cycle distribution analysis}

Cells were treated with CQ and zinc or DMSO for $4 \mathrm{~h}$, and then irradiated at $6 \mathrm{~Gy}$. Twenty-four $\mathrm{h}$ after irradiation, cells were harvested and fixed with ethanol at $4{ }^{\circ} \mathrm{C}$ overnight. All samples were then washed with PBS and resuspended in PI $(50 \mu \mathrm{g} / \mathrm{mL})$ and RNase A $(20 \mu \mathrm{g} / \mathrm{mL})$ in $\mathrm{PBS}$ for $30 \mathrm{~min}$ at room temperature by a previously reported method [11]. Stained cells were analyzed by flow cytometry (Beckman, USA). The data were expressed as the percentages of different cell cycle distributions.

\section{Luciferase activity assay}

Cells were grown in 100-mm dishes and were transfected with the NF- $\mathrm{KB}$ reporter construct (Palo Alto, CA, USA) using the Lipofectamine reagent (Invitrogen, Carlsbad, CA, USA), as previously described [9]. After $24 \mathrm{~h}$ of transfection, the cells were removed and plated into 96-well plates at 20,000/well. At $48 \mathrm{~h}$ of transfection, the cells were treated with $5 \mu \mathrm{M} \mathrm{CQ}$ and $10 \mu \mathrm{M}$ zinc for $4 \mathrm{~h}$ prior to treatment with $2 \mathrm{~Gy}$ of irradiation. After $24 \mathrm{~h}$ of irradiation, the luciferase activity was assayed using the luciferase assay reagent. Briefly, the cells were lysed using reporter lysis buffer, and the insoluble material was removed by brief centrifugation. A total of $30 \mu \mathrm{l}$ of luciferase assay reagent was mixed with $50 \mu \mathrm{l}$ of protein extract, and the luciferase activity was analyzed using a Microplate Reader (Thermo Fisher Scientific, USA). The relative light units were normalized for the amount of protein in each extract, and the results were reported as percentages of the values obtained from untreated cells.

\section{Gama-H2AX foci detection}

HeLa cells were seeded onto coverslips and were treated with $5 \mu \mathrm{M}$ CQ and $10 \mu \mathrm{M}$ zinc. After $4 \mathrm{~h}$ of coincubation with $C Q$ and zinc, the cells were irradiated with 4 Gy of $\gamma$-rays and were fixed, at intervals, in fresh 4\% paraformaldehyde, $250 \mathrm{mM}$ HEPES at $\mathrm{pH} 7.4$, and 0 . $1 \%$ Triton $\mathrm{X}-100$ for $20 \mathrm{~min}$ at $4{ }^{\circ} \mathrm{C}$. After washing 3 times in ice-cold PBS, the cells were permeabilized in 0 . $5 \%$ Triton X-100 for $20 \mathrm{~min}$ on ice and then were washed and blocked with $5 \%$ FCS in PBS at $37{ }^{\circ} \mathrm{C}$ for $30 \mathrm{~min}$. Coverslips were incubated with $\gamma \mathrm{H} 2 \mathrm{AX}$ antibody (Santa Cruz, CA, USA) overnight at $4{ }^{\circ} \mathrm{C}$. After washing with PBS three times for $5 \mathrm{~min}$, Alexa Fluor 488conjugated anti-rabbit secondary antibody was added for $1 \mathrm{~h}$ at $37^{\circ} \mathrm{C}$, and the slides were washed with PBS and stained with PI. Finally, the images were recorded on a confocal microscope (Bio-Rad), and nuclear foci were counted in 20-30 cells per field [12, 13]. Each experiment was carried out in triplicate.

\section{RNA extraction and quantitative real-time PCR}

MCF-7 cells were seeded onto 6-well plates and were treated with $5 \mu \mathrm{M}$ CQ and $10 \mu \mathrm{M}$ zinc. After $4 \mathrm{~h}$ of coincubation with $C Q$ and zinc, the cells were irradiated with 4 Gy of $\gamma$-rays. Twenty-four $h$ later, total RNA was isolated from cell lines using TRIzol reagent (Invitrogen, USA) according to the manufacturer's protocol. cDNA was synthesized from no more than $5 \mu \mathrm{g}$ of total RNA using a PrimeScript@ First-Strand cDNA Synthesis Kit (Takara, Japan) at $37{ }^{\circ} \mathrm{C}$ for $15 \mathrm{~min}, 85{ }^{\circ} \mathrm{C}$ for $5 \mathrm{~s}$, followed by $4{ }^{\circ} \mathrm{C}$ for $5 \mathrm{~min}$. Real-time PCR was performed with SYBR Premix Ex Taq ${ }^{\text {tax }}$ (Takara, Japan) in a $25-\mu \mathrm{L}$ reaction volume $(12.5 \mu \mathrm{L}$ of SYBR Green Mix (2X), $0.5 \mu \mathrm{l}$ of PCR forward primer, $0.5 \mu \mathrm{L}$ of PCR reverse primer, $0.5 \mu \mathrm{l}$ of ROX Reference Dye II (50x), $9 \mu \mathrm{L}$ of ddH2O and $2 \mu \mathrm{L}$ of cDNA template) using an MJ Opticon Monitor Chromo4 ${ }^{\mathrm{Tm}}$ instrument (Bio-Rad, CA). The human GAPDH gene was evaluated as an internal control. The following protocol was used for GAPDH and ATM (Santa Cruz, CA, USA): preincubation at $95^{\circ} \mathrm{C}$ for $7 \mathrm{~min}$, followed by 30 cycles of $95{ }^{\circ} \mathrm{C}$ for $30 \mathrm{~s}, 56^{\circ} \mathrm{C}$ for $35 \mathrm{~s}, 72{ }^{\circ} \mathrm{C}$ for $30 \mathrm{~s}$, and $72{ }^{\circ} \mathrm{C}$ for $10 \mathrm{~min}$. Sangon Biotech (Shanghai, China) assisted in the design and synthesis of the primers for ATM and GAPDH as follows: ATM (forward primer 5'-CCTACCAAATCCCTCCACC-3', reverse primer 5'-CCTTGAGCATCCCTTGTGTT-3'); GAPDH (forward primer 5'-TGGAAGGACTCATGAC CACA-3', reverse primer 5'-TTCAGCTCAGGGAT GACCTT-3'). The data were analyzed by the $2-\mathrm{DDCt}$ method.

\section{Western blotting}

Western blotting was performed as previously described [14]. Briefly, HeLa cells were treated with CQ and zinc for $4 \mathrm{~h}$ prior to treatment with $4 \mathrm{~Gy}$ of $\gamma$ irradiation and were lysed at intervals in a lysis buffer containing $50 \mathrm{mM}$ Tris/ $\mathrm{HCl}$ (pH 7.4), $100 \mathrm{mM} \mathrm{NaCl}, 5 \mathrm{mM} \mathrm{Na}$ /EDTA, $1 \mathrm{mM}$ PMSF, 0.1\% SDS, $1 \%(v / v)$ Triton X-100 and 2\% (v/v) glycerol. The lysates were separated by SDS/PAGE (15\% gels), transferred to a PVDF membrane, and blotted with antibodies against ATM, p65, $\gamma$-H2AX and $\beta$-actin.

\section{Statistical analysis}

The data were analyzed with GraphPad Prism 5.0 (GraphPad Software Inc., USA), using t-tests to determine differences between two groups and one-way analysis of variance (ANOVA) for three or more groups; $p<0.05$ indicated statistical significance.

\section{Results}

\section{Clioquinol combined with zinc induces cytotoxicity in HeLa cells}

To evaluate the anticancer effect of CQ and zinc on cancer cells, HeLa cells were treated with different concentrations 
of CQ and/or zinc. The CCK-8 assay revealed that the inhibitory effects elicited by CQ and/or zinc were dose dependent (Fig. 1). To evaluate the effect of CQ and zinc on the radiation sensitization of tumour cells, the $5 \mu \mathrm{M}$ $\mathrm{CQ}+10 \mu \mathrm{M}$ zinc group that induced approximately $15 \%$ inhibition of HeLa cell viability was selected for subsequent experiments.

\section{Clioquinol combined with zinc increases the radiosensitivity of cancer cells}

To investigate the influence of CQ and zinc on the radiosensitivity of cancer cells, we performed a clonogenic cell survival assay. Dose-survival curves were plotted according to the multi-target single-hit model (Fig. 2). Cells pretreated with $5 \mu \mathrm{M} C Q$ and $10 \mu \mathrm{M}$ zinc plus $\gamma$ ray irradiation exhibited significantly lower clonogenic survival fractions at each dose than cells treated with radiation alone. The sensitizer enhancement ratios (SERs) were 1.55 and 1.53 in HeLa cells and MCF-7 cells, respectively. Pretreatment with MG132 $(50 \mu \mathrm{mol} / \mathrm{L}$ for $2 \mathrm{~h}$ prior to CQ and zinc) enhanced the radiosensitivity in both cell lines, and the difference in the surviving fraction values compared with the $5 \mu \mathrm{M} C Q+10 \mu \mathrm{M}$ zinc group was not statistically significant $(p>0.05)$. Our results indicated that treatment with CQ combined with zinc-sensitized cancer cells to $\gamma$-ray irradiation through the NF- $\mathrm{kB}$ signalling pathway.

\section{Clioquinol combined with zinc induces apoptosis in HeLa cells}

Since reduced clonogenic survival was observed in the clonogenic cell survival assay, we next investigated whether it was resulted from increased apoptosis. As shown in Fig. 3, CQ and zinc treatment enhanced apoptosis in HeLa cells (CQ + Zinc $18.91 \%$ vs control $12.64 \%$, $p<0.05)$ and further enhanced the apoptotic response of HeLa cells to 6 Gy of irradiation [30.46\% (IR + CQ and zinc) vs $23.04 \%$ (IR), $P<0.01]$. Taken together, these results demonstrated that $\mathrm{CQ}$ and zinc enhanced radiation-induced apoptosis in HeLa cells.

\section{Clioquinol plus zinc combined with $\mathrm{\gamma}$-ray irradiation modulates the cell cycle distribution}

Flow cytometry was conducted to determine whether the CQ and zinc induced radiosensitization was associated with delay in cell cycle. As shown in Fig. 4, radiation induced G2/M arrest in HeLa cells. Compared with untreated cells post-irradiation, cells treated with $\mathrm{CQ}$ and zinc plus irradiation showed a decreased population of $\mathrm{G} 2 / \mathrm{M}$ arrest in HeLa cells (a reduction of nearly $20 \%, P<0.05)$. This result clearly indicated that $\mathrm{CQ}$ and zinc partly removed the radiation-induced G2 arrest.

\section{Clioquinol combined with zinc inhibits NF-кB activity}

To understand whether $C Q$ and zinc inhibit NF- $\kappa B$ activity in HeLa cells, cells were transfected with the pNF-kB-Luc reporter construct and treated with $5 \mu \mathrm{M}$ clioquinol and $10 \mu \mathrm{M}$ zinc for $4 \mathrm{~h}$ in the presence or absence of 2 Gy of irradiation. Next, we measured the luciferase activity of each group, data are shown in Fig. 5a. Compared with the control group (100\%), NF-kB activity was increased to $139 \%$ in the radiation group but was decreased to $33 \%$ in the CQ and zinc group. Compared with the radiation group (139\%), NF- $\mathrm{kB}$ activity was decreased to $39 \%$ in the CQ plus zinc combined with radiation group. Consistent with this observation, CQ and zinc decreased the total level of nuclear p65, the most frequently detected NF- $\mathrm{kB}$ subunit, in the presence or absence of radiation (Fig. $5 \mathrm{~b}$ ). Both of the above findings demonstrated that CQ and zinc down-regulated the NF$\kappa \mathrm{B}$ signalling pathway.

\section{Clioquinol combined with zinc treatment enhances DNA double-strand-break-induced IR}

The histone variant $\mathrm{H} 2 \mathrm{AX}$ and its phosphorylation on Ser139 (H2AX) is considered a specific DNA double-
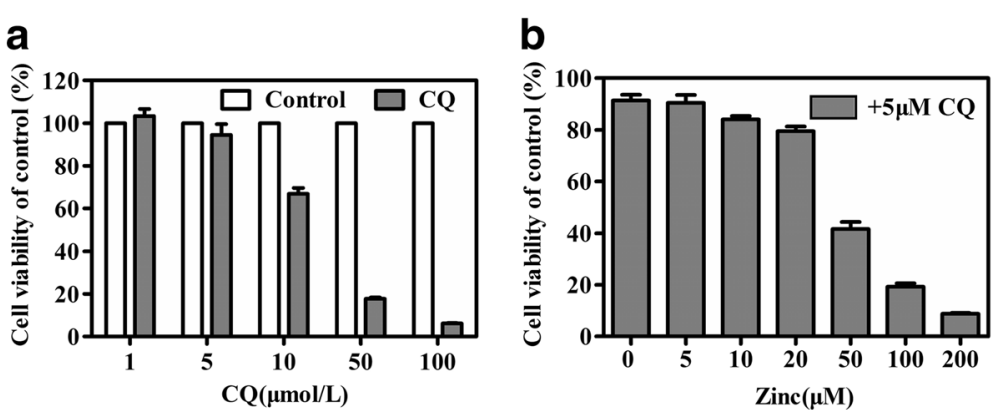

Fig. 1 Effects of CQ and/or zinc on the viability of HeLa cells. CQ (a) or CQ combined with zinc (b) induced cytotoxicity in HeLa cells. Cells were exposed to the indicated concentrations of CQ or CQ combined with zinc for $72 \mathrm{~h}$. Cell cytotoxicity was assessed by the CCK-8 assay. The data are shown as means \pm SEM of three independent experiments 

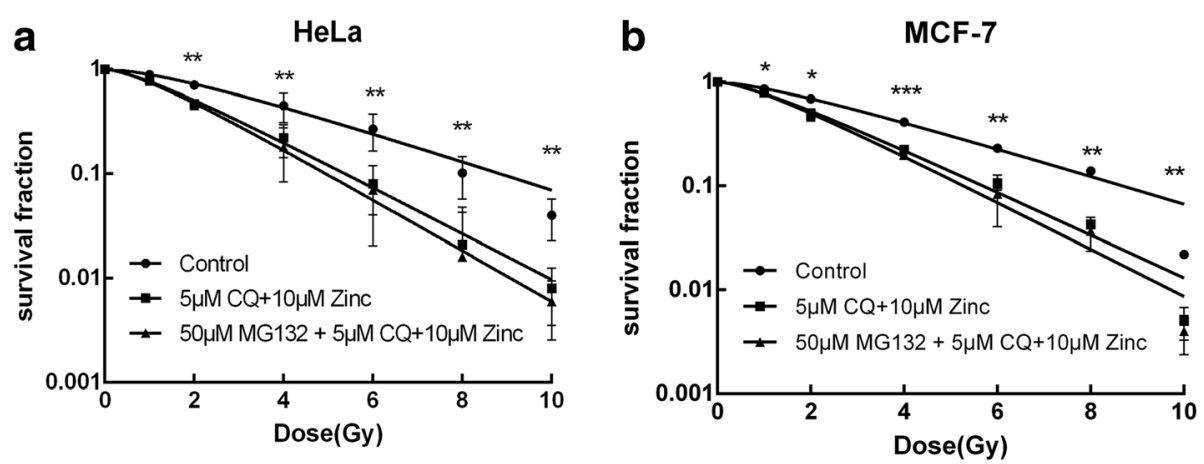

Fig. 2 Effects of CQ and zinc on the radiosensitivity of cancer cells. Clonogenic cell survival curves were generated for HeLa (a) and MCF-7 (b) cells that were treated with DMSO $5 \mu \mathrm{M} \mathrm{CQ}+10 \mu \mathrm{M}$ zinc $50 \mu \mathrm{M} \mathrm{MG} 132+5 \mu \mathrm{M} C Q+10 \mu \mathrm{M}$ zinc (MG132 for $2 \mathrm{~h}$ prior to CQ and zinc), and then were exposed to various doses $(0,1,2,4,6,8$ and $10 \mathrm{~Gy})$ of irradiation. The survival data were normalized to those of the unirradiated control group. The data are shown as the means \pm SEM for three independent experiments. ${ }^{* *} P<0.01$

strand-break (DSB) marker and an important event in the signalling and subsequent repair of DNA DSBs. The protein product of this reaction $(\gamma-\mathrm{H} 2 \mathrm{AX})$ accumulates at the sites of DSB, forming nuclear foci, where the number of foci is indicative of DNA DSB [13]. We assessed $\gamma-\mathrm{H} 2 \mathrm{AX}$ foci by immunofluorescence as shown in Fig. 6a and b. Cells showed weak fluorescence intensity before irradiation, significantly increasing after irradiation, and especially at $0.5 \mathrm{~h}$. The CQ and zinc group showed a higher mean fluorescence intensity than the control group in various time points and showed significant difference at $0.5 \mathrm{~h}$ and $24 \mathrm{~h}$. Additionally, we confirmed this consequence by western blotting (Fig. 6c). There was a significant excess of $\gamma-\mathrm{H} 2 \mathrm{AX}$ expression in the $\mathrm{CQ}$ and zinc group compared with that in the control group. Both findings indicated that $\mathrm{CQ}$ and zinc could
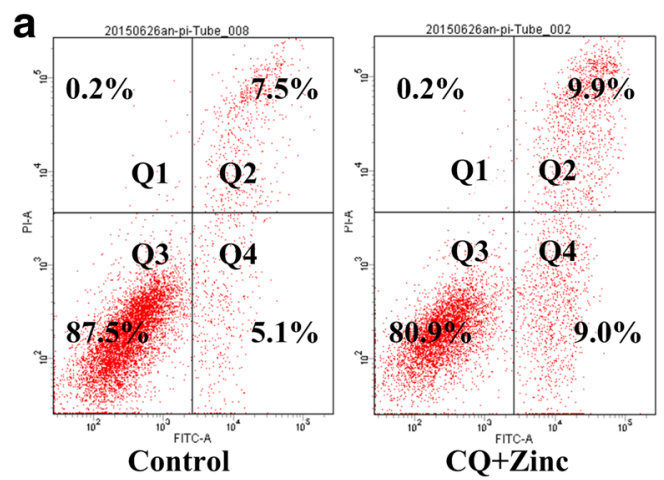

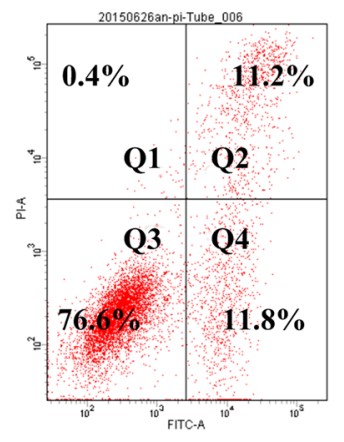

IR

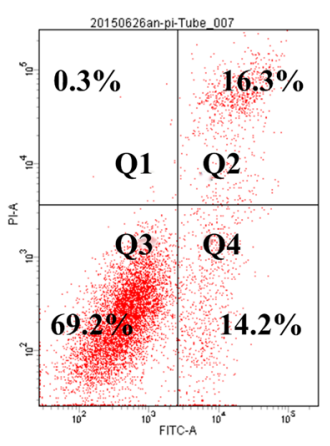

$\mathrm{CQ}+$ Zinc $+\mathrm{IR}$ b

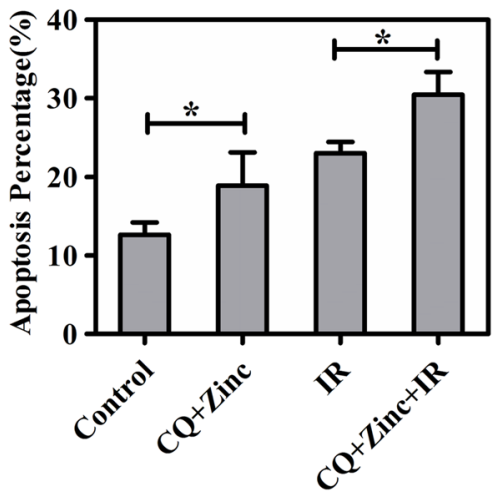

Fig. 3 Effects of CQ and zinc on the apoptosis of HeLa cells. $\mathbf{a}$ and $\mathbf{b}$ : Cells were treated with $5 \mu \mathrm{M} C \mathrm{C}$ and $10 \mu \mathrm{M}$ zinc for $4 \mathrm{~h}$ prior to treatment with 6 Gy of irradiation. Apoptosis was measured using propidium iodide (PI)/annexin $V$ double staining in HeLa cells. Representative images of three independent experiments are shown. ${ }^{*} P<0.05$ 


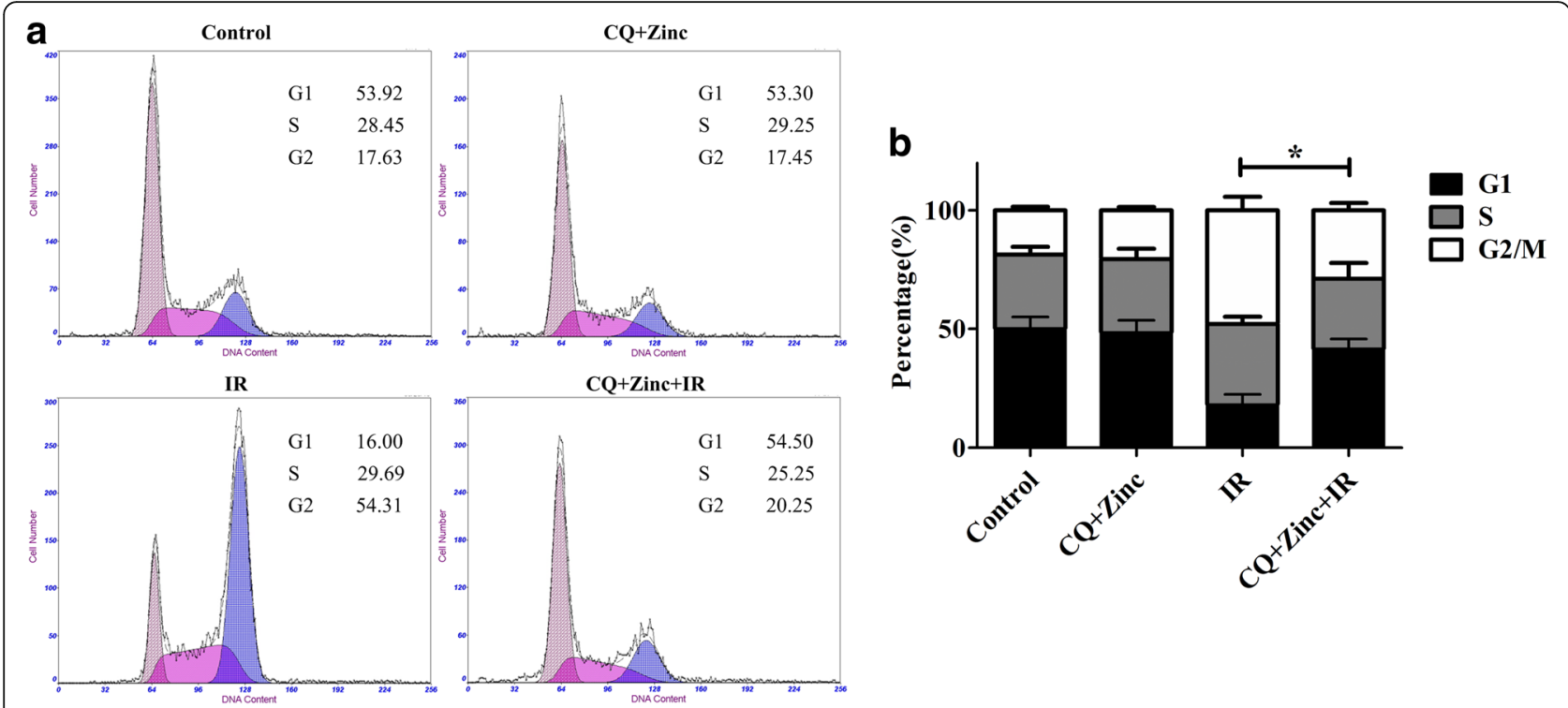

Fig. 4 Effects of CQ and zinc on the cycle progression of HeLa cells. a and b: Cells were treated with or without $5 \mu \mathrm{M} C Q$ and $10 \mu \mathrm{M}$ zinc for $4 \mathrm{~h}$ prior to exposure to $6 \mathrm{~Gy}$ of irradiation (IR). After $24 \mathrm{~h}$, both attached and floating cells were harvested for cell cycle analysis. Shown are representative images of three independent experiments. ${ }^{*} \mathrm{P}<0.05$

increase radiation-induced DNA DSBs, leading to a delay in the repair process that persisted for $24 \mathrm{~h}$.

\section{Clioquinol combined with zinc down-regulates the expression of ATM}

ATM is a critical protein of the DNA damage repair pathway, called the DNA damage receptor, and a downstream gene of the NF- $\kappa B$ signalling pathway. Real-time PCR and western blotting were used to analyse ATM expression after $24 \mathrm{~h}$ of irradiation. As shown in Fig. 7a and b, CQ and zinc down-regulated the expression of ATM both at the mRNA and protein levels with or without 4 Gy of irradiation. This finding establishes a link between the inhibition of the NF- $\mathrm{B}$ signalling pathway and DNA damage repair signal.

\section{Discussion}

Clioquinol and zinc were reported to induce apoptosis and cytotoxicity in different tumour cells, including prostate, ovarian, hepatoma, pancreatic, and breast cancers, but the effect of clioquinol and zinc on the radiosensitivity of tumour cells has not been fully studied [9]. Here, we found that clioquinol combined with zinc enhanced the sensitivity of cancer cells to ionizing radiation through the inhibition of inherent and radiationinduced NF- $\mathrm{B}$ activity, down-regulation of the DNA damage receptor ATM and increased DSBs, as well as variation of the cell cycle distribution and induced apoptosis.

We previously revealed that clioquinol combined with zinc treatment promoted apoptosis and down-regulated

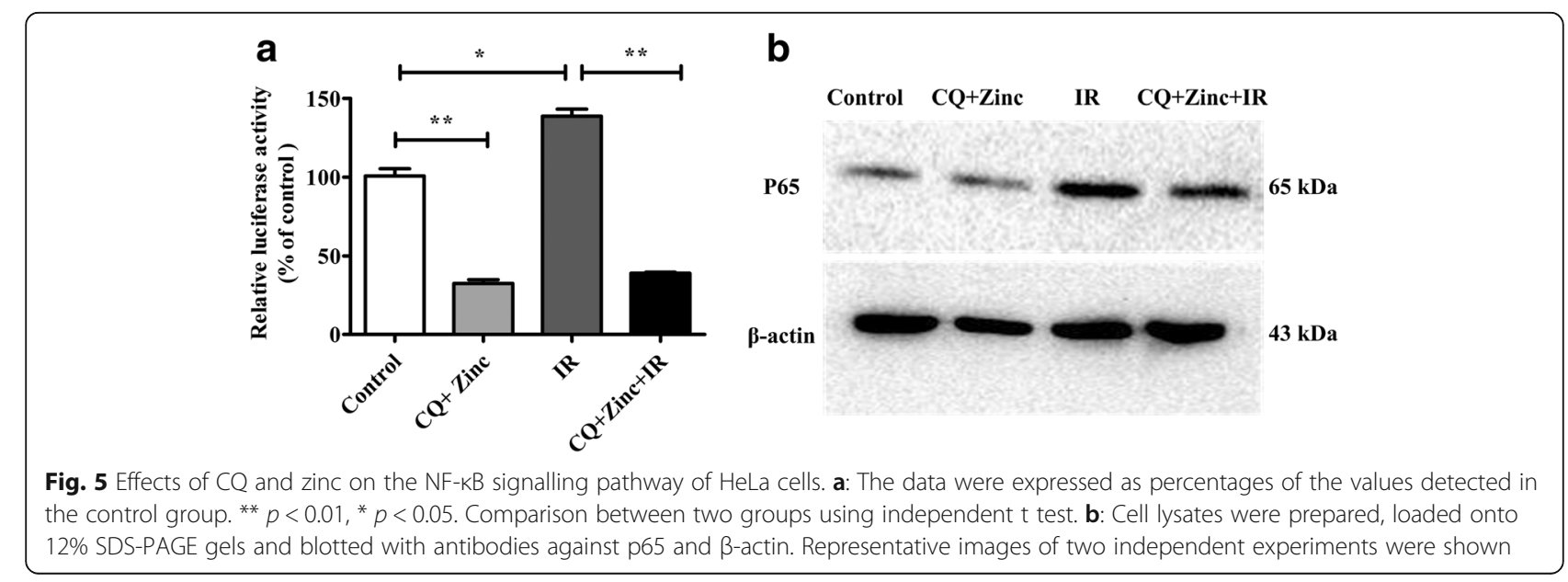




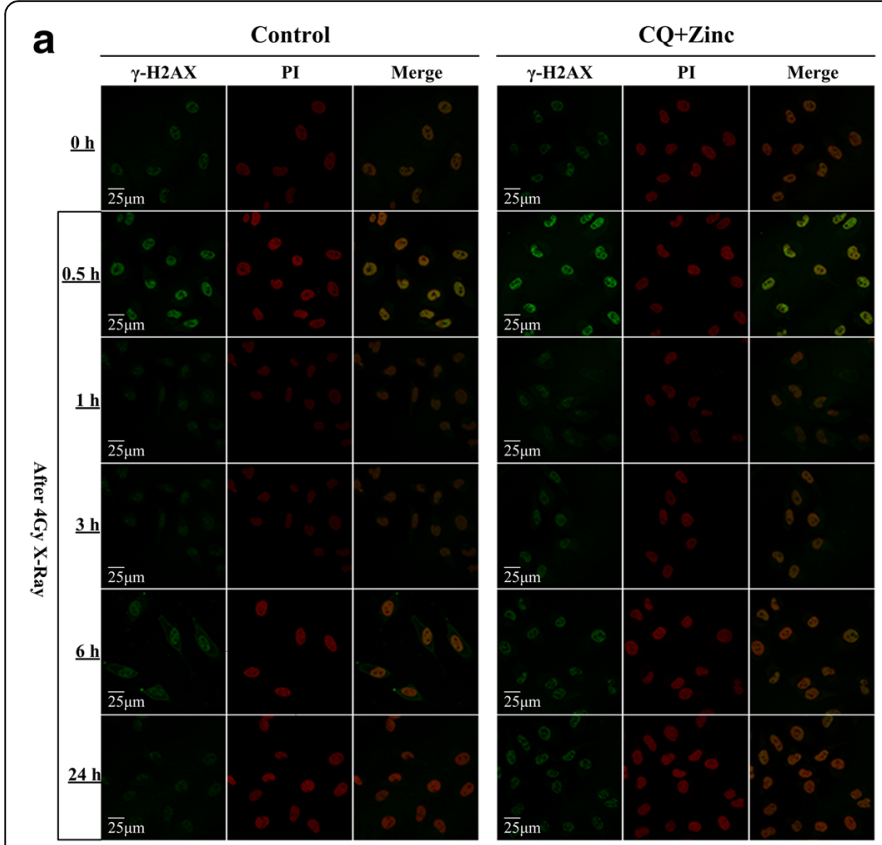

b
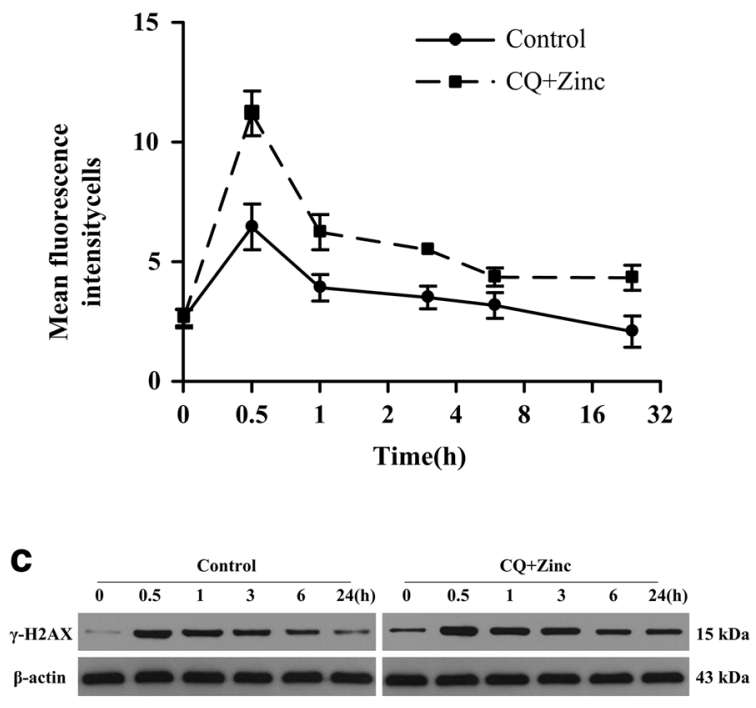

Fig. 6 Effects of CQ and zinc on the DNA damage dynamics of HeLa cells. a and $\mathbf{b}$ : Cells were treated with $5 \mu M$ CQ and $10 \mu M$ zinc in the presence or absence of $4 \mathrm{~Gy}$ of irradiation for $0.5-24 \mathrm{~h}$. The cells were stained with propidium iodide (PI) for 10 min and were examined under a confocal microscope. c: Cell lysates were prepared, loaded onto 12\% SDS PAGE gels (40 $\mu \mathrm{g}$ per well), and blotted with antibodies against $\gamma$-H2AX and $\beta$-actin. Shown are representative images of two independent experiments

cyclin D1 protein levels in cancer cells $[8,14]$. In the present study, we further proved that clioquinol combined with zinc promotes radiation-induced apoptosis and removes G2 arrest. Cell cycle checkpoints of cancer cells is activated when exposed to radiation. However, G1 checkpoint is absent in most cancer cells, commonly resulted from mutations or alterations of key regulators (p53 and Cyclin D1). While activation of the G2 checkpoint, operating primarily via a p53-independent mechanism, is rarely impaired. In fact, disruption of the G2 checkpoint often sensitizes cancer cells without a functional G1 checkpoint to radiation $[15,16]$. Taken together, our results indicated that clioquinol combined with zinc treatment increased the radiosensitivity of cancer cells through $\mathrm{G} 2$ arrest.

Our previous study found that clioquinol alone targeted NF- $\mathrm{KB}$ and lysosome pathways and inhibited NF$\mathrm{KB}$ activity in cancer cells, and the effect became more pronounced in the presence of zinc. Another study reported similar results [17]. In this study, we found that clioquinol combined with zinc significantly inhibited the endogenous and $\gamma$ radiation-induced activation of NF- $\mathrm{kB}$ in HeLa cells. NF- $\kappa B$ signalling is believed to be protumourigenic [18] and usually activated by DNA damage
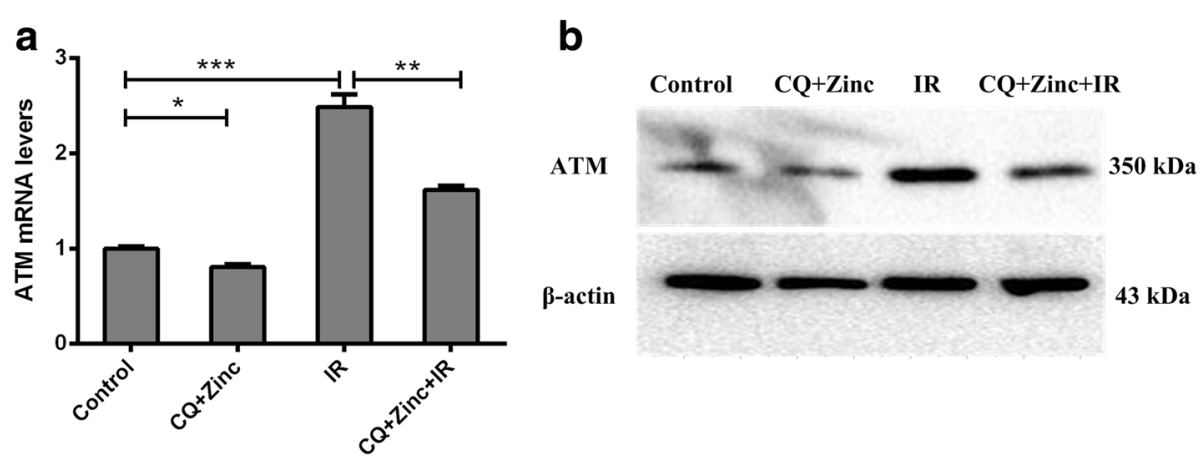

Fig. 7 Effects of CQ and zinc on the DNA damage repair of cancer cells. a Real-time PCR detected the relative ATM mRNA levels in the CQ + Zinc, Control, IR+ CQ + Zinc and IR groups. b Images from western blots to detect the relative ATM protein levels in the CQ + Zinc, Control, IR+ CQ + Zinc and IR groups. Shown are representative images of three independent experiments 
and inflammatory cytokines. It has been found to be in control of multiple cellular processes, including inflammation, transformation, proliferation, angiogenesis, invasion, metastasis, and chemo-radioresistance. Aberrant activation of NF- $\mathrm{KB}$ is commonly observed in different cancers [19]. Elevated NF- $\mathrm{B}$ DNA binding activity has been shown in both breast cancer cell lines and primary breast cancer tissues and contributes to malignant progression and chemo-radioresistance and promotes breast tumours metastasis [20]. Moreover, the induction of chemo-radioresistance and anti-apoptotic is mediated by several genes regulated by NF- $\mathrm{kB}$, and inhibition of this transcription factor increases the sensitivity of cancer cells to chemotherapeutic agents and radiation [21-24].

Thus, the inhibition of NF- $\mathrm{KB}$ represents a promising therapeutic strategy, and transient radiation-inducible $\mathrm{NF}-\mathrm{KB}$ activation presents a pro-survival response to radiation that may account for the development of radioresistance [25]. Our results suggested that clioquinol combined with zinc promotes the radiosensitization of HeLa cells and potentiates the antitumour effects of radiotherapy by blocking this signalling pathway.

It is believed that DNA double-strand breaks are the crucial cytotoxic lesion from ionizing radiation, and DNA damage and repair ability is critical for tumour cells to survive from radiation. The major methods for DSBs reparation are non-homologous end joining (NHEJ), single-strand annealing (SSA) and homologous recombination (HR). NHEJ is observed throughout cell cycle, while HR is limited to S/G2-phase of cell cycle [26]. To investigate the radiosensitizing mechanism of clioquinol combined with zinc, we evaluated DSBs damage and repair by quantifying $\gamma \mathrm{H} 2 \mathrm{AX}$ foci, the phosphorylated form of the variant histone $\mathrm{H} 2 \mathrm{AX}$, which is a marker of DSBs damage [27]. In our research, we demonstrated that clioquinol combined with zinc increased the formation of $\gamma$-ray irradiation induced $\gamma$-H2AX foci on both macro and micro levels and delayed the degradation of $\gamma-\mathrm{H} 2 \mathrm{AX}$ foci, apparent within $0.5 \mathrm{~h}$ of irradiation and sustained for $24 \mathrm{~h}$. Meanwhile, we found that clioquinol combined with zinc down-regulated the expression of ATM, which played a prominent role in DNA damage and repair. ATM is considered to be a primary transducer of cellular responses to DSBs and activate various damage response signalling pathways, including cell cycle checkpoints, DNA repair, and the induction of apoptosis, explaining why the ratio of G2 arrest declined to some extent. Although NF- $\mathrm{kB}$ target genes, encoding DSB repair factors, were identified, little is known about the functional role of NF- $\mathrm{kB}$ in DSB repair. It was previously shown that loss of p65 in murine fibroblasts compromised DNA repair and genome stability during cellular senescence [28]. However, contradictory conclusions were drawn in glioblastoma cells, where
NF- $\mathrm{kB}$ promotes the accumulation of ssDNA breaks and apoptosis [29]. Recently, it was revealed that NF-kB transcriptionally up-regulates ATM, and higher ATM kinase activity assures fully efficient HR through downstream signalling cascades, thus strongly stimulating the removal of DSBs [30].

Our findings established a link between the inhibition of the NF- $\mathrm{kB}$ signalling pathway and the DNA damage and repair process. We deduced that clioquinol combined with zinc inhibited NF- $\mathrm{KB}$ activity, leading to down-regulation of ATM, and deficient HR to remove DSBs.

\section{Conclusions}

As far as we know, the present research is the first to report that clioquinol combined with zinc could increase the radiosensitivity of cancer cells at a low toxic concentration. The putative mechanisms include the abolishment of G2 cell cycle arrest, enhancement of apoptosis, inhibition of the NF-kB-ATM pathway, induction of more DNA damage and inhibition of the repair of RTinduced DSBs damage. Our current findings support the notion that clioquinol combined with zinc is expected to be a promising treatment modality for cancer radiotherapy (RT), and we are planning on validating the effects of clioquinol combined with zinc in xenograft animal models.

\section{Abbreviations \\ CCK-8: Cell counting kit 8; CQ: 5-chloro-7-iodo-8-hydroxyquinoline; DMSO: Dimethyl sulfoxide; DSBs: Double-strand breaks; HR: Homologous recombination; NHEJ: Non-homologous end joining; RT: Cancer radiotherapy; SER: Sensitizer enhancement ratio; SSA: Single-strand annealing; SSD: Source skin distance \\ Acknowledgements \\ Not applicable. \\ Funding \\ This work was supported by the National Natural Science Foundation of China (Grant No. 81201755). The funding body had no role in the design of the study and collection, analysis, and interpretation of data and in writing the manuscript.}

\section{Availability of data and materials}

The datasets used and analysed during the current study are available from the corresponding author on reasonable request.

\section{Authors' contributions}

$S L, Y K$ and $C W$ performed all the experiments and data analysis, and $S L$ drafted the manuscript. YZ1, CX, YZ2 and FZ provided professional advice on the experimental design and reviewed the paper. $Y Z 1$ corresponded to Yahua Zhong. HY managed the experimental design, reviewed the manuscript and provided funding support. All the authors read and approved the final manuscript.

Ethics approval and consent to participate Not applicable.

Consent for publication

Not applicable.

Competing interests

The authors declare that they have no competing interests. 


\section{Publisher's Note}

Springer Nature remains neutral with regard to jurisdictional claims in published maps and institutional affiliations.

\section{Author details}

${ }^{1}$ Hubei Cancer Clinical Study Centre, Hubei Key Laboratory of Tumour Biological Behaviors, Wuhan, China. ${ }^{2}$ Department of Radiation and Medical Oncology, Zhongnan Hospital of Wuhan University, Wuhan, China. ${ }^{3}$ Hubei Cancer Clinical Study Centre, Zhongnan Hospital of Wuhan University, Wuhan, China. ${ }^{4}$ Department of Integrated Traditional Chinese Medicine and Western Medicine, Zhongnan Hospital of Wuhan University, Wuhan, China.

Received: 8 September 2017 Accepted: 20 March 2018 Published online: 20 April 2018

\section{References}

1. Prasanna PG, Narayanan D, Hallett K, Bernhard EJ, Ahmed MM, Evans G, Vikram B, Weingarten M, Coleman CN. Radioprotectors and Radiomitigators for improving radiation therapy: the Small Business Innovation Research (SBIR) gateway for accelerating clinical translation Radiat Res. 2015;184(3):235-48.

2. Russell ST, Siren PM, Siren MJ, Tisdale MJ. The role of zinc in the anti-tumour and anti-cachectic activity of D-myo-inositol 1,2,6-triphosphate. Br J Cancer. 2010;102(5):833-6.

3. Prasad AS, Beck FW, Snell DC, Kucuk O. Zinc in cancer prevention. Nutr Cancer. 2009:61(6):879-87.

4. Maret W. Molecular aspects of human cellular zinc homeostasis: redox control of zinc potentials and zinc signals. Biometals. 2009;22(1):149-57.

5. Gumulec J, Masarik M, Adam V, Eckschlager T, Provaznik I, Kizek R. Serum and tissue zinc in epithelial malignancies: a meta-analysis. PLoS One. 2014;9(6):e99790.

6. Wysokinski D, Blasiak J, Wozniak K. Zinc differentially modulates DNA damage induced by anthracyclines in normal and cancer cells. Exp Oncol. 2012:34(4):327-31

7. Sliwinski T, Czechowska A, Kolodziejczak M, Jajte J, Wisniewska-Jarosinska M, Blasiak J. Zinc salts differentially modulate DNA damage in normal and cancer cells. Cell Biol Int. 2009;33(4):542-7.

8. Yu H, Zhou Y, Lind SE, Ding WQ. Clioquinol targets zinc to lysosomes in human cancer cells. The Biochemical journal. 2009;417(1):133-9.

9. Ding WQ, Liu B, Vaught JL, Yamauchi H, Lind SE. Anticancer activity of the antibiotic clioquinol. Cancer Res. 2005;65(8):3389-95.

10. Jurisic V, Srdic-Rajic T, Konjevic G, Bogdanovic G, Colic M. TNF-alpha induced apoptosis is accompanied with rapid CD30 and slower CD45 shedding from K-562 cells. J Membr Biol. 2011;239(3):115-22.

11. Vuletic A, Konjevic G, Milanovic D, Ruzdijic S, Jurisic V. Antiproliferative effect of 13-cis-retinoic acid is associated with granulocyte differentiation and decrease in cyclin B1 and Bcl-2 protein levels in G0/G1 arrested HL-60 cells. Pathology Oncology Research. 2010;16(3):393-401.

12. Turney BW, Kerr M, Chitnis MM, Lodhia K, Wang Y, Riedemann J, Rochester M, Protheroe AS, Brewster SF, Macaulay VM. Depletion of the type 1 IGF receptor delays repair of radiation-induced DNA double strand breaks. Radiother. Oncol. 2012;103(3):402-9.

13. Bourton EC, Plowman PN, Harvey AJ, Zahir SA, Parris CN. The PARP-1 inhibitor Olaparib causes retention of $\mathrm{Y}$-H2AX foci in \&lt;i\&gt;BRCA\&lt;/i\&gt; heterozygote cells following exposure to gamma radiation. J. Cancer Ther. 2013:04(11):44-52

14. Zheng J, Benbrook DM, Yu H, Ding WQ. Clioquinol suppresses cyclin D1 gene expression through transcriptional and post-transcriptional mechanisms. Anticancer Res. 2011;31(9):2739-47.

15. O'Connell MJ, Cimprich KA. G2 damage checkpoints: what is the turn-on? J Cell Sci. 2005;118(Pt 1):1-6.

16. Chen T, Stephens PA, Middleton FK, Curtin NJ. Targeting the S and G2 checkpoint to treat cancer. Drug Discov Today. 2012;17(5-6):194-202.

17. Uzzo RG, Leavis P, Hatch W, Gabai VL, Dulin N, Zvartau N, Kolenko VM. Zinc inhibits nuclear factor-kappa B activation and sensitizes prostate cancer cells to cytotoxic agents. Clin Cancer Res. 2002;8(11):3579-83.

18. Sun F, Qu Z, Xiao Y, Zhou J, Burns TF, Stabile LP, Siegfried JM, Xiao G. NFkappaB1 p105 suppresses lung tumourigenesis through the Tpl2 kinase but independently of its NF-kappaB function. Oncogene. 2016:35(18):2299-310.

19. Chaturvedi MM, Sung B, Yadav VR, Kannappan R, Aggarwal BB. NF-kappaB addiction and its role in cancer: 'one size does not fit all. Oncogene. 2011; 30(14):1615-30.
20. Biswas DK, Shi Q, Baily S, Strickland I, Ghosh S, Pardee AB, Iglehart JD. NF-kappa $B$ activation in human breast cancer specimens and its role in cell proliferation and apoptosis. Proc Natl Acad Sci U S A. 2004;101(27):10137-42.

21. Ahmed KM, Li JJ. ATM-NF-kappaB connection as a target for tumour radiosensitization. Curr Cancer Drug Targets. 2007;7(4):335-42.

22. Wu ZH, Shi Y, Tibbetts RS, Miyamoto S. Molecular linkage between the kinase ATM and NF-kappaB signaling in response to genotoxic stimuli. Science (New York, NY). 2006;311(5764):1141-6.

23. Hellweg CE. The nuclear factor kappaB pathway: a link to the immune system in the radiation response. Cancer Lett. 2015;368(2):275-89.

24. Bai M, Ma X, Li X, Wang X, Mei Q, Li X, Wu Z, Han W. The accomplices of NF-kappaB lead to Radioresistance. Curr Protein Pept Sci. 2015;16(4):279-94.

25. Li F, Sethi G. Targeting transcription factor NF-kappaB to overcome chemoresistance and radioresistance in cancer therapy. Biochim Biophys Acta. 2010;1805(2):167-80.

26. Bennardo N, Cheng A, Huang N, Stark JM. Alternative-NHEJ is a mechanistically distinct pathway of mammalian chromosome break repair. PLoS Genet. 2008:4(6):e1000110.

27. Redon CE, Nakamura AJ, Zhang YW, Ji JJ, Bonner WM, Kinders RJ, Parchment RE, Doroshow JH, Pommier Y. Histone gammaH2AX and poly(ADP-ribose) as clinical pharmacodynamic biomarkers. Clin Cancer Res. 2010:16(18):4532-42.

28. Wang J, Jacob NK, Ladner KJ, Beg A, Perko JD, Tanner SM, Liyanarachchi S, Fishel R, Guttridge DC. RelA/p65 functions to maintain cellular senescence by regulating genomic stability and DNA repair. EMBO Rep. 2009:10(11):1272-8.

29. Karl S, Pritschow Y, Volcic M, Hacker S, Baumann B, Wiesmuller L, Debatin KM, Fulda S. Identification of a novel pro-apopotic function of NF-kappaB in the DNA damage response. J Cell Mol Med. 2009;13(10):4239-56.

30. Volcic M, Karl S, Baumann B, Salles D, Daniel P, Fulda S, Wiesmuller L. NF-kappaB regulates DNA double-strand break repair in conjunction with BRCA1-CtIP complexes. Nucleic Acids Res. 2012;40(1):181-95.

\section{Submit your next manuscript to BioMed Central and we will help you at every step:}

- We accept pre-submission inquiries

- Our selector tool helps you to find the most relevant journal

- We provide round the clock customer support

- Convenient online submission

- Thorough peer review

- Inclusion in PubMed and all major indexing services

- Maximum visibility for your research

Submit your manuscript at www.biomedcentral.com/submit
C) BioMed Central 